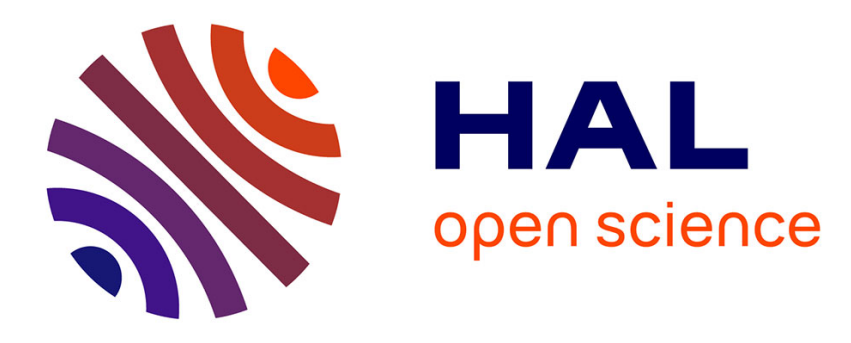

\title{
Economic and Industrial Issues in France's Approach to the German Question in the Post-War Period
}

\author{
Françoise Berger
}

\section{To cite this version:}

Françoise Berger. Economic and Industrial Issues in France's Approach to the German Question in the Post-War Period. Frédéric Bozo, Christian Wenkel. France and the German Question, 1945-1990, Berghahn, 2019, 978-1-78920-226-7. halshs-02921196

\section{HAL Id: halshs-02921196 \\ https://shs.hal.science/halshs-02921196}

Submitted on 2 Sep 2020

HAL is a multi-disciplinary open access archive for the deposit and dissemination of scientific research documents, whether they are published or not. The documents may come from teaching and research institutions in France or abroad, or from public or private research centers.
L'archive ouverte pluridisciplinaire HAL, est destinée au dépôt et à la diffusion de documents scientifiques de niveau recherche, publiés ou non, émanant des établissements d'enseignement et de recherche français ou étrangers, des laboratoires publics ou privés. 
in F. Bozo et allii, France and the German Question, 1945-1990, Berghahn (USA), 2019, p. 35-51.

\title{
CHAPTER 2
}

\section{Economic and Industrial Issues in France's Approach to the German Question in the Postwar Period}

\author{
FRANÇOISE BERGER
}

Evaluating French policies toward Germany during the Allied occupation period after the war has long been difficult because of both countries' sensitivity toward economic and industrial issues. These aspects were seldom studied apart from their negative consequences in the French Zone of Occupation (ZFO). This contribution aims to review the existing research and knowledge on France's postwar economic policies toward Germany from the wartime Free France projects up to 1955. ${ }^{1}$ It will highlight the importance of economic issues, which were far from being secondary for France. If a certain number of facts and explanations have long been established, recent historiography has enhanced the understanding of this policy area in the context of the beginnings of the Cold War.

Studying the economic aspects of France's attitude toward postwar Germany necessitates a multiple approach. Such an approach must cover France's economic policies in relation to Germany, the economic problems related to the national and European reconstruction and its interferences with the Marshall Plan, the policy regarding control of Germany in the context of the Allied occupation - necessarily a policy of compromise - as well as the more autonomous economic policy practiced in the ZFO. This involves multiple, more or less autonomous scales of

1. This contribution is complementary to Rainer Hudemann's contribution in this volume, which also covers the general historiography. 
decision and action. It is also necessary to include the question of reparations (including coal deliveries), which were very important for a French economy that was facing many difficulties during the reconstruction period, in particular before the announcement of the Marshall Plan. The question of restitutions, which also involved economic consequences, is also concerned, though in a more marginal way. ${ }^{2}$ Finally, we must consider the problem of foreign trade and the creation of new bilateral economic relationships in the context of the reconstruction and normalization of Europe.

Research on these economic issues started early and is still ongoing. With time, our understanding of the internal debates between the decision makers was deepened and prompted new perspectives on the periodization of these events. The context of the Cold War is clearly one of the reasons for the rather quick evolution of the French position, but the influence of the Europeanist circles was also important, leading to fast changes in the economic policy France carried out toward Germany. The position of economic milieus was also revised.

The first seminal writings on the topic showed that the French projects of 1945 had to adapt because of political and, above all, economic circumstances. First, it was necessary to take account of the three other Allies for the control of Germany (quadripartite agreements); then, starting in 1947, it became necessary to make concessions to the United States, which had set up the Marshall Plan. French historians initially presented French policy as eventually having had to yield to Anglo-Saxon pressure after a useless resistance. ${ }^{3}$

In the 1980s the opening of the French archives ${ }^{4}$ allowed a certain number of advances in knowledge, and also led, in the 1990s, to some partial reconsideration of the former analyses. While some historians continued to highlight French concerns ${ }^{5}$ about Germany, other authors ${ }^{6}$ relativized this fear and insisted on equally major and early fears in relation to the behavior of the

2. Unlike reparations, which were determined by an Allied commission to compensate for the losses of the victorious powers, the term "restitutions" refers to goods plundered during the war that are returned to their owners.

3. See Creswell and Trachtenberg, "France and the German Question.", 7.

4. France has the custody of the archives of the Allied Command (in Colmar until 2011, now in La Courneuve). See the very relevant remarks of Hudemann on the use of the archives in his contribution to this volume.

5. Poidevin, "Plan Marshall et problème allemand.", 87-96.

6. See, e.g., Hudemann, “L’occupation française en Allemagne.”, 221-42. 
Union of Soviet Socialist Republics (USSR, or Soviet Union) as early as July $1945^{7}$ —in other words, even before the real start of the Cold War.

Explanations must take the considerable complexity of the issue into account. ${ }^{8}$ Contrary to the nonrealistic vision of French policy still defended by some, it should be stressed that political actors were in effect completely aware of the realities, even if this did not lead to a change in the official position of France, which - in a realistic way - had to take various elements into account, starting with public opinion and the country's urgent reconstruction needs. ${ }^{9}$ Other works, focusing on the economic aspects, have explored the apparent ambiguities of a French policy caught between domestic and Allied constraints. ${ }^{10}$ These works nuanced predatory interpretations ${ }^{11}$ of the French attitude ${ }^{12}$ by showing, for example, that if the production of the ZFO was partly oriented toward French needs, it was also partly focused on the needs of the ZFO itself. The question of the reparations and compensations was also linked to the general principles of French economic policy toward Germany. ${ }^{13}$ Finally, we now know much more about the evolution of the French project for Germany up to $1949 .{ }^{14}$

Apart from the official approach, the actions of the economic milieus have also been studied, showing hesitations but also a certain amount of goodwill from French entrepreneurs, albeit slowed down by or lacking support from the French authorities. ${ }^{15}$ This discrepancy between the political and industrial circles is particularly noticeable in the iron and steel industry, where, as

7. Ibid., 232; Creswell and Trachenberg, "France and the German Question," 7-8.

8. Rainer Hudemann has insisted on this for a long time in various articles, and so have I in my previous research (see, e.g., Berger, La France, l'Allemagne). This point of view has been recently confirmed by Michael Creswell and Marc Trachenberg, even if their position does not enjoy unanimous support. See Creswell and Trachtenberg, "France and the German Question"; Creswell and Trachtenberg, "New Light on an Old Issue?" See, in the same special issue of Journal of Cold War Studies, three contradictory answers to the former article.

9. Creswell and Trachenberg, "France and the German Question."

10. Hüser, Frankreichs “doppelte Deutschlandpolitik."

11. This vision was primarily developed by German authors. The feelings of the population influenced German historians because German sources, in particular the press, were negative.

12. Lefèvre, Les relations économiques.

13. Maelstaf, Que faire de l'Allemagne?

14. Libera, Un rêve de puissance. Libera presents a fine synthesis of the evolutions until 1949, in particular the large variety of the first projects that had been elaborated before the middle of 1945. Gérard Bossuat had already mentioned ten projects dating back before December 1944, and four more plans between July and September 1945; see Bossuat, "Les conceptions françaises," 27.

15. Eck, Les entreprises françaises; see also Berger, La France, l'Allemagne, 809-11. 
early as 1946, relatively short-term objectives were being set regarding the rebuilding of an industrial cartel with Germany. ${ }^{16}$ In 1949, when the Federal Republic of Germany (FRG, or West Germany) was created, what the French entrepreneurs feared above all was not German competition but the interventionism of the public authorities. ${ }^{17}$

These successive and complementary works thus refined and complexified the understanding of French economic policy toward Germany, first and foremost in terms of the chronology of the evolution (both public and secret) of France's approach to the German question, but also concerning the influence of the context, the constraints, and the objectives. These works made it possible to gain insight into the debates and the divergences among politicians as well as ministries. They also showed the differences between the various levels of French intervention (foreign policy, inter-Allied policy, policy in the ZFO). Finally, they led to a more realistic assessment (in spite of the persistent stereotypes) of the actual results of French policy, particularly in the ZFO.

Taking these elements into account, as well as the above-mentioned discrepancies between declared objectives and perceived realities, and the strong — internal and external — constraints, we are able to present a revised periodization of French economic policy toward Germany, whose evolutions do not follow the same rhythm as the more political aspects of the German question as seen from France. The broad outlines of this multiform economic policy are well-known even if the policy has not been studied as comprehensively as the security aspects. However, recent research has contributed to a better understanding of the question, and it brings to light the dichotomy between the discourse aimed at influencing French public opinion — which, in addition to a feeling of revenge, showed concern and lassitude facing the economic difficulties of the first postwar period-and the semiofficial but real evolutions taking place in the occupied zones, including secret negotiations with the Anglo-American Allies. Consequently, the general characterization of France's policies toward Germany has not been completely revised, but rather has been split into two categories: discourse and reality. We can find several examples of these

16. Such a cartel was not considered to be immediately convenient, but only because France had not yet reconquered enough market shares to hold a sufficiently strong position in an international negotiation. In 1948 semiofficial negotiations to that end nevertheless started; see Berger, La France, l'Allemagne, 871-72.

17. Berger, La France, l'Allemagne, 866. 
discrepancies between official texts or declarations, and internal documents from the various ministries and authorities. ${ }^{18}$

What also arises is the need for parallel observation on the various levels of French economic policy. Such observation tends to reinforce the idea of an apparent ambiguity of that policy, but it also partly explains the contradictions by showing the different constraints on each level, and the amount of leeway given to the actors in the field. This constant change of scale must be accompanied by a fine periodization, which is not exactly the same for the general policy and for the policy concerning the ZFO. We can distinguish four main phases, including the last part of the war period, because that is the moment when the first French economic project for Germany was drawn up.

\section{The Prehistory of the French Economic Project for Germany, 1942-45}

We now know that, from 1942-43 to 1945, the National French Council, which was chaired by General Charles de Gaulle, gave rise to many projects with regard to France's policies toward Germany. These projects converged to some extent; priority was given to security, an aspect that seems to have been almost obsessional for de Gaulle ${ }^{19}$ and for most of the political actors of the Resistance - an aspect that obviously was related to Germany's potential heavy industry production and, thus, of armament. As a result, attention was focused on the main economic areas, in particular the Ruhr, but also the whole of Rhineland-Westphalia as well as the Saarland. In these neighboring territories, the French state had ambitions of control, even of annexation, but it also had needs for coke supply. This simple equation was a source of friction: How could Germany compensate France, Belgium, or Great Britain without rousing fear of the reawakening of the industrial power that had led to the war? These interrogations took past experiences into account, because no one wanted a solution that could be harmful in the long term, as had happened in 1919.

18. Gaps of the same type were also pointed for the United States and Great Britain, undoubtedly less important but quite real; see Creswell and Trachtenberg, "France and the German Question."

19. Yet if de Gaulle did play a central role in the decision-making process, he hardly participated in the development of these projects, whose authors were, essentially, senior officials; see Libera, Un rêve de puissance, 71. 
By 1942 some possible solutions were outlined. ${ }^{20}$ From 1943 onward the examination of the economic outlooks for the postwar period resulted in about ten projects. ${ }^{21}$ Do these projects in effect amount to an overall policy of economic disarmament? ${ }^{22}$ Be that as it may, security was the main focus, involving military disarmament and economic measures that would prevent any future rearmament of Germany. ${ }^{23}$ The men and networks in charge of these various projects formed a rather homogeneous group of decision makers, in London or Algiers, but also in Paris, in the various administrations, which took part. ${ }^{24}$

Although the economic question was at the heart of these projects, contrary to what was long affirmed $^{25}$ no industrialists nor economists were consulted, not unlike what happened in the first postwar period when the government's plans were little appreciated in business circles because they did not take account of European geoeconomic realities. ${ }^{26}$ The detachment of the Ruhr from German territory was undoubtedly the element that received the most support until February 1945, both among the French and among the Allies within the Inter Allied Armistice Study Committee. ${ }^{27}$ Only the project carried by Pierre Mendès-France did not involve this separation, yet it fell under

20. "Problèmes économiques de l'après-guerre, un point de vue français," note by Hervé Alphand (director of economic affairs in the French Ministry of Foreign Affairs), quoted in Bossuat, "Les conceptions françaises," 26.

21. See a useful chart in Bossuat, "Les conceptions françaises," 26; and a fine analysis of the projects in Libera, Un rêve de puissance, 73-103.

22. Bitsch, "Un rêve français", 313, n2.

23. The project evoked by Marie-Thérèse Bitsch was refined in 1944 within the French delegation to the London-based Inter Allied Armistice Study Committee (CIEA), which included ministers of foreign affairs and experts from various Allied nations; see Conway and Gotovitch, Europe in Exile, 117, n53. This committee, which was created on 23 October 1942, according to Martial Libera was in charge of studying the "necessary measures to ensure the military, naval and air disarmament of the enemy and to prevent its rearmament, in particular through the implementation of economic measures" (Libera, Un rêve de puissance, 49). Specialized subcommittees focused on the industrial, financial or commercial questions and were in charge of working out proposals for the European Advisory Commission (EAC), which had been agreed on at the Moscow Conference of Oct. 1943; in charge of the study of the postwar political problems in Europe and the drafting of recommendation to the three major allied governments, it was terminated in Aug. 1945. See FRUS 1945, European Advisory Commission, Austria, Germany, vol. $3,883-1147$.

24. For this period, Libera's contribution is essential, because he studies in detail these various projects and the men and networks who designed them: see Libera, Un rêve de puissance, 39-134.

25. According to Libera, Un rêve de puissance, 141-43: "In 1945, there is no doubt that the majority of the decision-makers were fully aware of the prominent role of the economy as a deciding factor of power.

Paradoxically, however, it was the defenders of the traditional designs (...) who imposed their views."

26. See Berger, "Les relations entre les sidérurgies," 172.

27. See Libera, Un rêve de puissance, 145. 
an economic imperialist aim, like many of the other French projects, as it hoped to reverse the balance of power in the iron and steel-making industry to the benefit of France. ${ }^{28}$ The case of Saarland, a major coal-providing territory (hence a very important asset for the European economy), was also in question, but it was treated in another way: the Saarland was separated from the German territory, and put under a French governor until the Saarland people chose in 1956, after long bilateral negotiations, to join Germany. ${ }^{29}$

All these projects wanted to weaken the defeated country, but René Mayer and Hervé Alphand's projects were definitely more moderate in scope. Among the lot, only one project clearly stood out, namely that of Jean Monnet, who advocated, from 1943 onward, an equal treatment with the objective of a complete European overhaul. Monnet's project, however, was too innovative to be taken seriously given the situation of France in $1943 .{ }^{30}$ With the final victory against Germany in May 1945, the French provisional government (GPRF) could publicly proclaim its ambitions (i.e., to rebuild France's industry, particularly its steel industry) thanks to German coal and to the production limitations of defeated Germany - an approach that was similar to the one that France adopted after World War I. ${ }^{31}$

\section{French Requirements and Allied Constraints, May 1945-May 1948}

After the fall of the Third Reich, the economic policy that France was planning to carry out in Germany was already quite different from the early projects, but the debates continued: from July to September 1945 four other plans were refined. ${ }^{32}$ Clearly, those advocating a very firm position had the upper hand, but they were far from the position of total intransigence that some continued to recommend. ${ }^{33}$ Discussions with the Allies within the Inter Allied Armistice Study Committee also led to a note by the GPRF dated 7 July 1945, "Note on the economic and financial disarmament of Germany." 34 Following the very convincing argumentation of Creswell and

28. Ibid., 137.

29. See Hudemann and Poidevin, Die Saar.

30. Ibid., 100.

31. See Berger, "Les relations entre les sidérurgies."

32. Bossuat, "Les conceptions françaises.", 27.

33. This included Pierre Mendès-France.

34. See Bitsch, "Un rêve français.", 313-29. 
Trachtenberg, we can make the assumption that while it advocated a very uncompromising stance, such a stance in fact no longer reflected the conceptions of the time, which had already moved to a more moderate approach to policies with regard to Germany; the meaning of disarmament has been somewhat inaccurately interpreted along the lines of a "total (both military and economic) disarmament." Similarly, the plans to separate the Ruhr area, at least after May 1945, were no longer taken very seriously. ${ }^{35}$

It was during the Potsdam Conference (17 July to 2 August 1945) that the new French authorities, having just gained control of the ZFO that was allotted to them, issued a first series of directives. ${ }^{36}$ In them, they tried to define the priorities of France's action in Germany; the principal problem therein was the choice between helping reconstruction and maintaining security —in other words, between the possibility of counting on German reparations that left the possibility for a German economic recovery in the medium term, and the possibility of decreeing the economic disarmament of the country in order to obtain security in the long term. ${ }^{37}$ French economic policy toward Germany was caught for months in this hesitation, even if, officially, it was the security requirement that prevailed.

Among the decisions made within the Allied Control Council was the industrial plan of 28 March 1946 that limited Germany's total industrial production to 50 percent of its level of 1938 (this level had not been reached yet). This question of the maximum level of German production was recurrent, because it quickly became obvious that production had to be increased in order for the German territories to attain self-sufficiency. At the same time, Germans had to make the deliveries imposed under the repair. The Allies did not want to finance Germany's subsistence in any way, but that country's economic and social situation was extremely difficult. This situation also led the French to develop their own position regarding reparations pursuant to the decisions made at the Potsdam Conference. True, French policy in this field was still not clearly defined in January 1947. ${ }^{38}$ Yet a few months later, with the Cold War now under way (and after the French communist ministers had been ousted in May 1947), the French position seemed to evolve significantly and

35. Creswell and Trachtenberg, "France and the German Question."

36. Note : "Gouvernement provisoire de la république française: Directives pour notre action en Allemagne," 20 Jul. 1945 (quoted by Hudemann, “L’Occupation française en Allemagne.”. 37. Libera, Un rêve de puissance, 147-50.

38. Bossuat, "Les conceptions françaises." 32. 
get closer to the U.S. and British positions: on 2 December 1947 Foreign Minister Georges Bidault explained that France "allows the principle of reparations to be taken from the current production, under the condition ... that they not be used as a pretext for an excessive increase of the level of German industry."39 Though Germany's competitive potential was undoubtedly one of the reasons - though not officially acknowledged - for the fear of such an "excessive increase," the limitation of Germany's industrial production was also seen as having potentially fatal consequences on the French and European industrial needs. In fact, on 5 December 1947 Bidault officially agreed to ease the restrictions and allow a production of 10 million-12 million tons of steel, whereas in March of the same year he had claimed that "steel [the whose production was set at 7.5 million tons in March 1946] is among the first industries that will be permanently limited." "40 French concerns with regard to German competition did not always appear in an obvious way in the public discourse. True, in March 1947 Bidault explained that the limitation of German steel production was justified not only for security reasons, but also "by the need to allow the peaceful countries to increase their own production and to reinforce their industrial power." He added, "If Germany needs more steel, its neighbors will be able to provide it." 41 Yet internal documents reflect, from very early on, a realistic understanding that it was simply not possible to block German industry for too long.

Meanwhile, on the question of creating a customs union between the Ruhr area and France, the French faced a wall of opposition from the Allies, who offered Saarland as a concession. ${ }^{42}$ On 30 March 1947 Bevin declared himself favorable to the economic union of Saarland and France, and he reiterated this proposal to General Marshall, the U.S. secretary of State, on 10 April $1947 .^{43}$

\section{French Economic Policy in the ZFO}

In the meantime, since the end of the war the French command had been facing concrete problems in the ZFO that were quite different from the concerns of the government in Paris. The military

39. Siegfried, L'année politique, 251.

40. Ibid., 55.

41. Ibid., 55-56.

42. "The Anglo-Saxons give the impression that, to draw us away from the Ruhr, they want to satisfy us in Saarland". (Siegfried, L'année politique, 82).

43. Ibid. 
government of the ZFO was responsible, from September 1945 onward, of the "control of the German economy as a whole, within the French zone, "44 with very broad powers in all economic sectors. The economic policy of the ZFO theoretically depended entirely on him. Thus, the French military authorities had designed, from the very first moments of the occupation, an economic policy and precise methods to carry it out. Implementation of the policy was not free of hesitations or blunders, but it was far from the accusations of being completely improvised or wanting to transform the ZFO into a kind of autarky.

The French military authorities aimed at a balanced management of the ZFO, both in order to allow deliveries to France and to prove that they were able to face this responsibility. The serious economic difficulties of the ZFO required compromises. Control of the German economy had a dual dimension: first, the French exercised tight control over all economic activities of the area, and second, they had the monopoly over foreign trade. But the head of the civil administration of the ZFO, Emile Laffon, also had to control the economy of the ZFO. ${ }^{45}$ Therefore, there was a double set of internal tensions. Measures concerning the ZFO itself, divided between the military government led by General Koenig and the civil administration led by Laffon, often followed different priorities. The military government was more independent in its action ${ }^{46}$ and furthermore, the two men were often in personal conflict. Thus, tensions between the official directives coming from Paris and the on-site needs led to situations that were difficult to manage. There emerged two types of policies for the ZFO: those decided in Paris, and the actions in the ZFO themselves by both Koenig and Laffon.

There were also a couple of local factors that made this situation even more complex. The administrative fragmentation of the ZFO, which comprised eight different units, made it much more difficult to manage than the other Allied zones. It was made up of whole or parts of preexistent regional units that did not have any administrative structure in common. ${ }^{47}$ And there was another difficulty: even though, from a political point of view, France was opposed to an

44. Ordinance no. 5 of the French commander in Germany, 4 Sept. 1945 (Libera, Un rêve de puissance, 227).

45. Libera, Un rêve de puissance, 227.

46. Dietmar Hüser explained this very well: From the beginning, the objectives of France were moderate despite national pressure (domestic politics) or international constraints (the need to negotiate with the Allies). See Hüser, Frankreichs "doppelte Deutschlandpolitik."

47. Abelshauser, "Wirtschaft und Besatzungspolitik," 114. 
administrative centralization of Germany ${ }^{48}$ from an economic standpoint, the French authorities felt the need for a measure of coordination with the two other Western zones. Because the Potsdam agreements stipulate that "during the period of occupation, Germany shall be treated as an economic unit, " a note from the French military headquarters stated as early as 15 December 1945, that "allowing excessive economic disparities to develop between our zone and its neighboring zones would be counterproductive and these disparities would most likely be interpreted as divergences of policy. Such divergences, indeed, should not occur, since the aims we are pursuing are the same ones as our Allies." The document also specified that the decisions made during the negotiations in Berlin would be strictly enforced in the ZFO. ${ }^{49}$ Moreover, the same document explained that, insofar as the French did not have the necessary staff, it would be in France's best interest to allow a German administration to emerge, especially because they would be more able to impose "the obligations resulting from defeat" on the population. Economic disarmament was also mentioned; its main goal was the destruction of war factories and any factories essential in times of war. ${ }^{50}$ Finally, because of the relatively low industrial potential of the FZO, it was necessary to maintain relationships with the other zones. Yet this made the situation even more complex, because the Allies used the French economic requests to gain leverage on political issues. ${ }^{51}$

The creation of the Anglo-American Bizone in January 1947, without French participation, is a perfect example of the contradictions between these two levels of action. France did not join the Bizone until June 1948: Although such a move was long hoped for by the administration in the ZFO, mostly for economic reasons, it was opposed by many in Paris. In January 1948 René Massigli, France's ambassador to London, complained to Jean Chauvel, the secretary general of the minister of foreign affairs, about Paris's attitude concerning the plan of merging the Allied

48. France's opposition to administrative centralization derived not only from the fear of a resurgent Reich, but also, according to recent work (see, e.g., Creswell and Trachtenberg, "France and the German Question"), from the fear of a Soviet takeover of German central administrations that would thus put the Soviet danger at the French border. (The debate on this subject was still important in 1945.)

49. Directives de politique économique et financière, 15 Dec. 1945, AnF, 462 AP, box 26.

50. Ibid.

51. R. Hudemann describes "the swift, uninterrupted fight carried out by General Koenig to improve the food supply of his zone" against all the French and Allied administrations (see Hudemann, "L'occupation française en Allemagne," 237-38). 
zones. ${ }^{52}$ General Koenig seemed open to the negotiation, but he did not want to precipitate it because the fusion would also have undesirable political consequences. When a reorganization plan of the Bizone was drawn up, the European department of the French ministry of foreign affairs complained that it had not been consulted even though the planned reorganization, though primarily economic in scope, could, in the long term, have consequences on the political organization of Germany. ${ }^{53}$ Massigli argued that, if France was interested in the Bizone, it should join it or else stop complaining about not being included. The ministry shared his opinion on the subject: "It is eminently regrettable that we delayed the fusion of our zone and the Bizone." 54 Even though the economic fusion between the ZFO and the two other Allied zones did not take place until June 1948, considerable changes in the objectives and discourses had started to appear in early 1948.

\section{Observing the New Germany and Beginning Cooperation, June 1948-May 1952}

From the agreement of 1 June $1948,{ }^{55}$ which initiated the process of the creation of a German federal state, the French position evolved quickly, both generally speaking as well as regarding economic policy in particular. Realism was now the order of the day: "The aim of the London agreements was the political and economic restoration of Germany, " Robert Schuman declared. ${ }^{56}$ The production restrictions (decreed for security reasons) were not abandoned; they would be facilitated by the new statute of occupation, starting from the creation of the FRG in May $1949 .{ }^{57}$

52. Letter by Massigli to Chauvel, 10 Jan. 1948, MAE, DDF, 1948, vol. 1, 56-57.

53. Note of the Division of European Affairs, 12 Jan. 1948, DDF 1948, vol. 1, 63-65.

54. Ibid.

55. The London Conference from Feb. to Jun. 1948 agreed on 1 June 1948 to initiate a process of creating a German federal state with broad legislative and administrative powers that was nevertheless demilitarized and under occupation statute. The London Conference also agreed to create an International Authority for the Ruhr in charge of coordinating and controlling its economic activity in the Ruhr area.

56. Robert Schuman's speech on the origins and the development of the ECSC in Bruges, Belgium, on 22 Oct. 1953. .

57. The Washington Agreement of 8 April 1949 ratified the creation of the FRG and a revision of the occupation statute. It was followed on 8 May 1949 by the promulgation of the Fundamental Law of the FRG. On 9 November 1949, in Paris, the conference of the three Western powers integrated the FRG into the Western bloc by allowing it to join the various international organizations of the West: the Organisation for European Economic Co-operation (OEEC), the Council of Europe, and the International Authority for the Ruhr. To allow for this, the Petersberg Agreement was signed on 22 November 1949 between the three Allied high commissioners and Konrad Adenauer. 
The International Authority for the Ruhr, created on 28 December 1948, marked the beginning of a Franco-German economic and financial, in particular in the ZFO. From this time on, industrial dismantling in the name of reparations was clearly slowed down in the Bizone; France nevertheless continued this practice in spite of German protests-yet another ambiguous policy.

Starting in May 1948, and as a consequence of the Marshall Plan and the pressure from the Americans to include the Western part of Germany in the Western camp, we notice a complete reversal in the French official position on economic policy. ${ }^{58}$ A note from the French Ministry of Foreign Affairs urged a change in the economic policy toward Germany and highlighted the importance of seeking European economic solidarity. ${ }^{59}$ Almost at the same moment, the plan drawn up by the Commissariat au Plan (the French Planning Commission) considered the potential contribution of a rebuilt Germany with which egalitarian economic relations could be restored. ${ }^{60}$ The European option was clearly favored, thanks not only to the Europeanist convictions of the majority of the decision makers of the time and to the growing influence of this thinking in public opinion, but also to realism. The new foreign minister starting in September 1948, Robert Schuman, was not a naive Europeanist: he remained on the defensive toward Germany. Yet Schuman was ready to implement a radical new policy; his arrival at the Quai d'Orsay, which quickly involved a change of staff, transformed the situation. His appointment (official as of 15 December 1948) of André François-Poncet, a close acquaintance of his, as adviser to General Koenig, was instrumental in changing French policies. (François-Poncet became high commissioner with the creation of the FRG, a position that he kept until the end of the occupation statute in 1955. He was the only one of the Allied high commissioners to remain in office throughout all this period.) As France's former ambassador to Berlin, François-Poncet knew prewar Germany quite well, and he was particularly interested in the economic issues. ${ }^{61} \mathrm{He}$ was experienced in negotiations in this field and was well informed about the evolution of Germany's

58. After the May 1947 dismissal of the four communist ministers, it took some time for the government to make a real change in its priorities: the main enemy became the USSR rather than Germany, even if public opinion was reluctant to follow this new position (the communists voters were nearly 30 percent in 1947).

59. Note of 21 May 1948, quoted by Bossuat, "Les conceptions françaises.” 33.

60. Ibid., 34.

61. See Berger, "André François-Poncet." 
economic situation from the beginning of the Allied occupation. ${ }^{62}$ As a long-time Europeanist activist, he was representative of the dominant positioning of Schuman's entourage - and of their contradictions, because they were at the same time wary of a German recovery and intent on building a pacified Europe based on economic cooperation. In May 1948 François-Poncet took part in the Hague Conference that founded the European Movement, of which he was a very active member. His abundant diplomatic correspondence reflects the interrogations of an engaged Europeanist about French policy priorities and their evolution. ${ }^{63}$ It shows that, from 1949 onward, things had clearly changed from an economic standpoint: the prospects for European construction were already present-particularly in the Schuman Plan, which counted on German economic power to be a pillar of this construction. The will for economic cooperation was stressed, but, at the same time, the fear of competition remained very present, in particular after the monetary reform that helped stabilize the German economy.

The French point of view is indeed often ambiguous concerning this cooperation. What dominates, however, in the writings of the ambassador are the security concerns. Schuman spoke of an "increasing discomfort” felt after the Petersberg agreements (November 1949): "We applied a new policy with old methods: i.e., we made many very large, important and well-intentioned concessions, but always bitterly negotiated, concessions wrest away from the reticent and mistrustful winners by a nation which had been defeated and was humiliated by having to beg for them." ${ }^{64}$ In the economic domain, this resulted in the growing focus around the Ruhr problem (even though Germany had reluctantly agreed to join the International Authority for the Ruhr as a result of the Petersberg Agreement). Plans for dismantling German industry became even more controversial, especially toward the end of 1949. The French leaders were well informed of the agitation caused by the plans, in particular in Berlin, agitation that was encouraged by widely divergent views of the Western Allies on this question. "In our opinion, it is quite likely that the imminent dismantling of the Borsig plants in Berlin will raise a wave of indignation against us

62. For example, on 15 December 1945 he received from the military headquarters a folder on the situation and on the economic policy in the ZFO, perhaps to prepare a leading article or one of the lectures which he readily gave on these subjects in the years to follow (AnF, 462 AP, box 26). 63. See his monthly reports starting in May 1949 published by Hans Manfred Bock (Bock, Les rapports mensuels).

64. Robert Schuman's speech on the origins and the development of the European Steel and Coal Community in Bruges, 22 Oct. 1953. 
and will be likely to cause incidents. Furthermore, the protest movement has the support of the industrialists and even of local civil servants. " 65 Despite complaints, the French continued the dismantling (which shows the limits of American pressure), even if they did not directly reap any benefits from it, arguing that they were only applying the Allied group decisions. However, the French high commissioner's comments show that he understood Adenauer's position quite well: Adenauer was asking, in a moderate way, for a slowing down of the dismantling. François-Poncet wrote that Adenauer "was looking forward to starting negotiations with the Allies, and particularly with France, with the objective of substituting the dismantlings with a system which would establish a balance between Allied concerns on security issues, i.e., limiting Germany's war potential, and Germany's ability to fund the reparations." characteristic style of François-Poncet, was his way of diplomatically calling for a change in the government's position and of pointing out the gap with the Allies on this issue.

At the time of the devaluation of the mark in October 1949, France was able to impose its point of view: it successfully recommended a rate of about 20.5 percent whereas the German federal government, backed by the American and British high commissioners had proposed a rate of 25 percent. The French found benefits in limiting the fall of the value of the mark for obvious trade reasons: the lower the mark, the more German products would be competitive against French products. The French high commissioner considered that, "without a doubt, this is a success for us. ${ }^{67}$ The affair caused some tension within the high commission because it was a decision of major importance for the country "whose economic activity it must control and guide." actions taken by the high commission clearly show that France and its representative were able to maintain certain room for maneuver, particularly concerning economic affairs, in spite of the constraints previously discussed.

Even if German foreign trade was never really interrupted (although this issue had been a source of permanent conflict since the beginning of the French occupation $)^{69}$ it was then officialized and the new partners joined the negotiating table. It gave Germany a form of equality that was difficult

65. Report of the French high commissioner, 19 Oct. 1949 (Bock, Les rapports mensuels, vol. 1, 191-92). 66. Ibid., 193.

67. Ibid.

68. Ibid.

69. See Libera, Un rêve de puissance, 416-28; Eck, Les entreprises françaises, 17-61. 
for the French to accept, especially because Germany's quick economic recovery worried France, which was facing economic difficulties of its own. However, France required outlets for its agricultural and industrial production and wanted to purchase capital equipment produced in Germany, which, thanks to the quick recovery of the country's solid infrastructure, was of good quality and sold at competitive prices. Pushed by this need, it was therefore very tempting to turn to the FRG, in spite of the fear of helping it to reinforce its industry. ${ }^{70}$ The easing of tensions happened very gradually. In consequence, although "the German authorities really wanted the first agreement that they were authorized to negotiate to be a Franco-German agreement, "71 the first negotiations, similar to those that would follow throughout this period, were particularly tense, with sharp discussions, aggressive language, session adjournments, threats, and ultimatums of all kinds, with the Germans seen as the eternal culprit. These negotiations were difficult. ${ }^{72}$ They nevertheless led to the first Franco-German trade agreement signed on 18 February 1950 (not yet a true treaty because German foreign trade was still under allied control) which provided for strictly defined quotas of product imports on both sides. This system was highly criticized by the Germans for its lack of economic liberalism and because they felt that the quota constraints would tamper with fair competition. The German economic liberal model was already quite different from the more statist French model. ${ }^{73}$ Still, nearly 60 percent of the exchanges were liberalized, their full amount was doubled, the procedures were simplified and-this was the great innovation - the two countries used their respective currencies, the franc and the mark, which reduced the deficits in dollars to which they both were confronted (the dollar was used only as an accounting currency). ${ }^{74}$ This agreement, which was valid for only six months (but thereafter regularly renewed for an identical period of time), was greeted with approval; the German press presented it as "a general rehearsal before free trade." 75 Even if this assertion was a little

70. Berger, Les relations économiques.

71. 29 Nov. 1949, AD, Europe 4.22.2, box 357.

72. French reluctance seemed to be the result of pressure by French protectionist circles, though the French accused the Germans of delaying the signature in order to put pressure on France in the Saarland issue. The agricultural problem was not the only one to create tensions between France and Germany. In the German iron and steel industry, the new trade agreement, which opened the doors of the German market to some iron and steel French products, received very little support (Director Georgen's letter to the six factories of the iron group, 8 Mar. 1950, Bundesarchiv, B 109/97, WVESI).

73. See Berger, "France-Allemagne."

74. Journal Officiel, 14 Feb. 1950.

75. 16 Feb. 1950, (Centre des archives économiques et financières, B 33890). 
premature, bilateral exchanges quickly represented a significant part of both countries' foreign trade. ${ }^{76}$

The declaration of 9 May 1950 was the solution finally found by Schuman and Monnet to ease the tensions and put an end to the balancing act between negotiations and outdated requirements. ${ }^{77}$ After almost a year of difficult negotiations,${ }^{78}$ it led to the signature of the Treaty of Paris creating a European Coal and Steel Community (ECSC) on 18 April 1951. After this date, there was a significant change of attitude illustrated, for example, by a clear evolution of the attitude of the Allied high commissioners toward German authorities, giving the federal government almost complete control and partly becoming a rubber stamp.

\section{A Slow Normalization of Relations and the Final European choice, May 1952-May 1955}

On 26 May 1952 the three Western powers signed a convention on the statute of the FRG, which granted it full sovereignty not only on national affairs, but also on international relations as a result of its entry into the new European Defence Community (EDC). The end of the occupation statute was swiftly anticipated and the French high commissioner even announced his impending departure months in advance. ${ }^{79}$

Yet in spite of the change of tone effective since the Schuman proposal, French public opinion remained opposed to the German rearmament under the guise of European projects, and this eventually led to the rejection of the EDC after long months of waiting (on 30 August 1954). Consequently, the agreement could not come into force and it was necessary to quickly find another solution. To that end, the agreements of Paris (October 1954) enabled the regularization of this situation as of the following year. In the meantime, the situation was rather strange. In

76. Berger, Les relations économiques.

77. In a context where the French knew that they would not go on controlling German production for much longer - particularly steel production - it was a compromise designed to keep some control in the future and, at the same time, doing a neighborly act opening the way to a European construction including Germany.

78. These negotiations started in 1950 under an unequal statute and were marked by concessions gradually wrested by the German delegation to obtain equal treatment. See Berger, "Le compromis franco-allemand."

79. See Extracts of press, 3 Jan. 1952, AnF, 462 AP, box 29. 
practice, Germany had already gained its equal treatment in the economic domain, and the ECSC had come into force 23 July 1952, but the Allied high commission was still not dissolved, even if its role was now reduced to keeping record of the decisions. As for the Saarland question, it remained present over the whole period because the problem was only solved in 1956 in favor of Germany. The economic questions were obviously decisive in this dispute, but they were far from being the only decisive ones. On 5 May 1955 the agreements of Paris of October 1954, which gave the new German republic its sovereignty, came into effect. The Allied high commissioners became ambassadors. From the commercial point of view, the two countries become each other's largest trading partners. The page of the postwar period could be turned.

To summarize, one must highlight the great disparities between the very rigid official discourses on France's economic approach toward defeated and occupied Germany, and the more realistic policies implemented by the French ministry of economy and in the ZFO. The image given by the harshness of French demands, at the beginning of the occupation period, simply does not correspond to the actual practices.

In this respect, the most recent research has made it possible to refine knowledge on the constraints brought by the nascent Cold War, on the apparent contradictions between the official objectives and the necessary adaptations on site, on the perception of the various scales of the implementation, as well as the internal dissensions between the decision makers, including the French administrations themselves. The Soviet danger-contrary to what was long asserted-was perceived quite early on (1945-46) and its influence on French policy is very clear, from the Marshall Plan onward. In other words, decision makers understood early on that the part played by the German economy in Europe's recovery and security (indirectly, through its financial contributions), was essential, considering Western Europe's new situation faced with the Soviet threat. If the French discourse remained very firm, it was not because of ideological differences, but because, even under those conditions, France did not want to give up anything it deemed necessary to its economic development and because politicians and decision makers believed that public opinion was still not ready for change. 


\section{Conclusion}

France's economic policy toward Germany during the decade following the war has been reevaluated. It has been shown that it was a lot more constructive than we long thought, involving a quick and pragmatic acceptance of Germany's economic recovery starting in the beginning of the postwar period, because France and Europe definitely needed it for its own restoration. Thus, the context of the Cold war and anti-Soviet mistrust ${ }^{80}$ _ except among the communist circles — as well as the pressure from Europeanist groups, led the French governments to revise their policy in order to enable a true economic cooperation whose effects were felt rather quickly, as early as the first months of the FRG. In 1955 France thus became Germany's number one trading partner, and reciprocally. Furthermore, as of the following year the widened European economic project was promoted jointly by the Franco-German couple, which subsequently became the economic engine of European construction.

Françoise Berger is associate professor of contemporary history at the Institute of Political Studies (Grenoble, France). She is a member of the Commission for the Publication of French Diplomatic Documents (on World War II). Research topics: Franco-German economic and diplomatic relations in the twentieth century, economic and diplomatic aspects of World War II, European economic constructions, European industrial history. Recent publications : "Le haut-commissariat français et la nouvelle Allemagne (1949-1955)," in Frankreich in Deutschland seit 1870 : 150 Jahre diplomatische Präsenz, edited by M. Aballea and M. Osmont (2017); "Le ministère français des Affaires étrangères face au blocus économique contre l'Allemagne: objectifs et stratégie," in L'Industrie française dans la Grande Guerre, edited by Fridenson (2018).

\section{Bibliography}

Abelshauser, W. 1983. "Wirtschaft und Besatzungspolitik in der Französischen Zone 1945-1949." In Die Deutschlandpolitik Frankreichs und die französische Zone 1945-1949, edited by C. Scharf and H.J. Schröder, 111-39. Wiesbaden, Germany: Franz Steiner.

Berger, F., 1991. Les relations économiques de la République française avec la République fédérale d'Allemagne sous statut d'occupation. Master thesis, University of Paris 1, under the supervision of René Girault.

- 2000. La France, l'Allemagne et l'acier 1932-1952. De la stratégie des cartels à l'élaboration de la CECA. Doctoral diss., University of Paris 1, under the supervision of René Girault.

80. This was particularly clear in André François-Poncet's view, which makes his writings interesting, because he struggled - as most of the French people did — between a rather primary anticommunism and a defensive standpoint against a Prussian Germany, which he had known before and during the war. 
2004. "Le compromis Franco-allemand dans l'industrie sidérurgique." In Die Bundesrepublik Deutschland und die europäische Einigung 1950-2000. Bewegende Kräfte und politische Akteure, edited by M. König and M. Schulz, 379-99. Stuttgart, Germany: Franz Steiner Verlag.

- 2005. "André François-Poncet, des réseaux intellectuels à l'expérience du journalisme économique au service des entrepreneurs." In Les permanents patronaux. Eléments pour l'histoire de l'organisation du patronat en France dans la première moitié du XXe siècle, edited by O. Dard and G. Richard, 75-92. Metz, France: Centre régional universitaire lorrain d'histoire.

— 2007. "Les relations entre les sidérurgies française et allemande de 1870 à la CECA." Revue d'Allemagne et des pays de langue allemande 39, no. 2: 163-99.

- 2012. "France-Allemagne. Stratégies comparées sur la longue durée.” Outre-Terre 33-34: 21331.

Bitsch, M.-T. 1987. "Un rêve français. Le désarmement économique de l'Allemagne 1944-1947." Relations internationales 51: 313-29.

Bock, H. M., ed. 1996. Les rapports mensuels d'André François-Poncet, haut-commissaire français en Allemagne 1949-1955, 2 vols. Paris: Imprimerie nationale.

Bossuat, G. 1997. "Les conceptions françaises des relations économiques avec l'Allemagne 1943-1960." In Die deutsch-französischen Wirtschaftsbeziehungen 1945-1960/Les relations économiques franco-allemandes 1945-1960, edited by A. Wilkens, 25-62. Sigmaringen, Germany: Thorbecke.

Conway, M., and J. Gotovitch, eds. 2001. Europe in Exile. European Exile Communities in Britain 19401945. New York: Berghahn Books.

Creswell, M., and M. Trachtenberg. 2003. "France and the German Question 1945-1955." Journal of Cold War Studies 5, no. 3: 5-28.

- 2003. "New Light on an Old Issue?" Journal of Cold War Studies 5, no. 3: 46-53.

Eck, J.-F. 2003. Les entreprises françaises face à l'Allemagne de 1945 à la fin des années 1960. Paris: Comité pour l'histoire économique et financière de la France.

Hudemann, R. 1990. "L'occupation française en Allemagne. Problèmes généraux et perspectives de recherche." In L'Allemagne occupée 1945-1949, edited by H. Ménudier, 221-42. Brussels, Belgium: Complexe.

Hudemann, R., and R. Poidevin, eds. 1992. Die Saar 1945-1955. Ein Problem der europäischen Geschichte. Munich, Germany: Oldenbourg.

Hüser, D. 1996. Frankreichs "doppelte Deutschlandpolitik." Dynamik aus der Defensive: Planen, Entscheiden, Umsetzen in gesellschaftlichen und wirtschaftlichen, innen- und außenpolitischen Krisenzeiten 1944-1950. Berlin: Duncker \& Humblot.

Lefèvre, S. 1998. Les relations économiques Franco-allemandes de 1945 à 1955. De l'occupation à la coopération. Paris: Comité pour l'histoire économique et financière de la France.

Libera, M. 2012. Un rêve de puissance. La France et le contrôle de l'économie allemande 1942-1949. Brussels, Belgium: Peter Lang.

Maelstaf, G. 1999. Que faire de l'Allemagne? Les responsables français, le statut international de l'Allemagne et le problème de l'unité allemande 1945-1955. Paris: Imprimerie nationale.

Poidevin, R. 1993. "Plan Marshall et problème allemand : les inquiétudes françaises 1947-1948." In Le plan Marshall et le relèvement économique de l'Europe, edited by R. Girault and M. Lévy-Leboyer, 87-96. Paris : Comité pour l'histoire économique et financière de la France.

Siegfried, A., ed. 1948. L'année politique 1947. Paris: Grand siècle. 